\title{
Development Situation of Industrial Zones in Bac Giang Province, Viet Nam
}

\author{
N. T. Dung, P. T. M. Hanh, and N. H. Nam
}

\section{ABSTRACT}

Through analysis of industrial zone development, the research shows that the industrial zones of Bac Giang province, Vietnam are in the stage of rapid development, along with the emergence of industrial zones, the proportion of industrial, foreign direct investment in the province increases and solve a number of employees for the province and neighboring areas. However, the level of increase is still limited. In addition, the province's workforce comes mainly from rural areas, so the quality of the labor force is not high; the ability to apply scientific advances to production is limited. This causes difficulties in the development of industrial zones in the province. The research gives a number of recommendations and solutions for industrial zone development.

Keywords: Bac Giang Province, Industrial Zone, Industrial Zone Development, Viet Nam

Published Online: December 22, 2021

ISSN: $2736-660 \mathrm{X}$

DOI: $10.24018 /$ ejdevelop.2021.1.4.52

\section{N. T. Dung}

Bac Giang Agriculture and Forestry University, Vietnam.

(e-mail: nguyenthidungktkt81@ gmail.com) P. T.M. Hanh*

Thai Nguyen University of Economics and Business Administration, Thai Nguyen, Vietnam.

(e-mail:phungtranmyhanh.tueba@ tueba.edu.vn)

N.H. Nam

Bac Giang Agriculture and Forestry University, Vietnam.

(e-mail: hainam23876@gmail.com)

*Corresponding Author

\section{INTRODUCTION}

Industrial zones play an important role in socio-economic development as an address to attract investment capital, contribute to economic growth and restructuring, create jobs, improve the quality of human resources, improve national technological capacity, promote local economic development and accelerate urbanization (Phan Tien Ngoc, 2006). Therefore, the Government of Vietnam has paid attention to the development of Nghi Son industrial park. 23-NQ/TW dated March 22, 2018 of the Politburo with the goal of industrialization and modernization, basically becoming a modern industrialized country in the group of 3 leading countries in ASEAN in terms of technology.

Bac Giang is a mountainous province with a favorable location for industrial park development. Currently, the province has 6 industrial zones which are favorable conditions for attracting foreign investment capital, creating jobs, and developing the local economy. However, Bac Giang's industrial zone has many limitations, such as: infrastructure development in many industrial zones is slow to be fully and synchronously invested. In addition, a number of departments, branches and localities have not been active in investment promotion and projects face many difficulties in the implementation process, especially in the stage of compensation, site clearance and land access, have premises to implement the project (Viet Hung, 2019). The article studies the current situation of development of Bac Giang industrial zones, from which, proposes appropriate solutions to promote the development of Bac Giang industrial zones, contributing to the province's socio-economic development. 


\section{EMPIRICAL ANALYSIS AND DISCUSSION OF RESUlTS}

\section{A. Situation of Industrial Zones in Bac Giang Province}

Bac Giang is a province located in the economic corridors Hanoi - Hai Phong, Lang Son -Nanning (China).In 2019, in terms of FDI capital alone, Bac Giang is the 6th province in the country in terms of FDI attraction after Ho Chi Minh City, Binh Duong, Dong Nai, Hanoi and TayNinh.BacGiang has 6 industrial zones with an area of about 1,371 ha (Dinh Tram Industrial Park, Song Khe-Noi Hoang Industrial Park, Quang Chau Industrial Park, Van Trung Industrial zone, Viet Han Industrial zone, HoaPhu Industrial zone).

Currently, the reality shows that the established industrial zones have attracted the majority of investors from Japan, Korea, China, the United States, Hong Kong, Singapore, Japan, Taiwan, Samoa... with cumulative total licensed projects up to 2019 is 147 with a total registered capital of USD 5,081.3 million (Bac Giang Statistical Office, 2020).

TABLEI:INDUSTRIAL ZONE IN BAC GIANG PROVINCE, VIETNAM

\begin{tabular}{cllc}
\hline \hline No. & \multicolumn{1}{c}{ Industrial zone } & \multicolumn{1}{c}{ Location } & Planned area (ha) \\
\hline 1 & HoaPhu & HiepHoa district, Bac Giang province & 207,45 \\
2 & Van Trung & Viet Yen district, Bac Giang province & 350,3 \\
3 & Viet Han & Viet Yen district, Bac Giang province & 197,31 \\
4 & Dinh Tram & Viet Yen district, Bac Giang province & 127 \\
5 & Quang Chau & Viet Yen district, Bac Giang province & 426 \\
6 & Song Khe - Noi Hoang & Viet Yen district, Bac Giang province & 158,7 \\
\hline \hline
\end{tabular}
Source: Bac Giang Industrial zone Project Management Board.

\section{B. Development Situation of Industrial Zones in Bac Giang Province}

To have a comprehensive view of industrial development, the study and assessment of industrial park development in Bac Giang province is based on industrial production value, foreign direct investment and labor force in the province's industrial park. Value of industrial production - construction includes industrial zones. Table I shows that in the period of 2015 - 2019, the proportion of industry - construction of the province has gradually increased. This is a proof that the district has a certain position in the industry of the province. Within the industry-construction production value in the IZ accounts for a significant proportion compared to outside the IZ. In 2015, the industrial production value accounted for nearly $37 \%$.By 2019, the proportion of industrial production value is increasing, accounting for over $53 \%$.

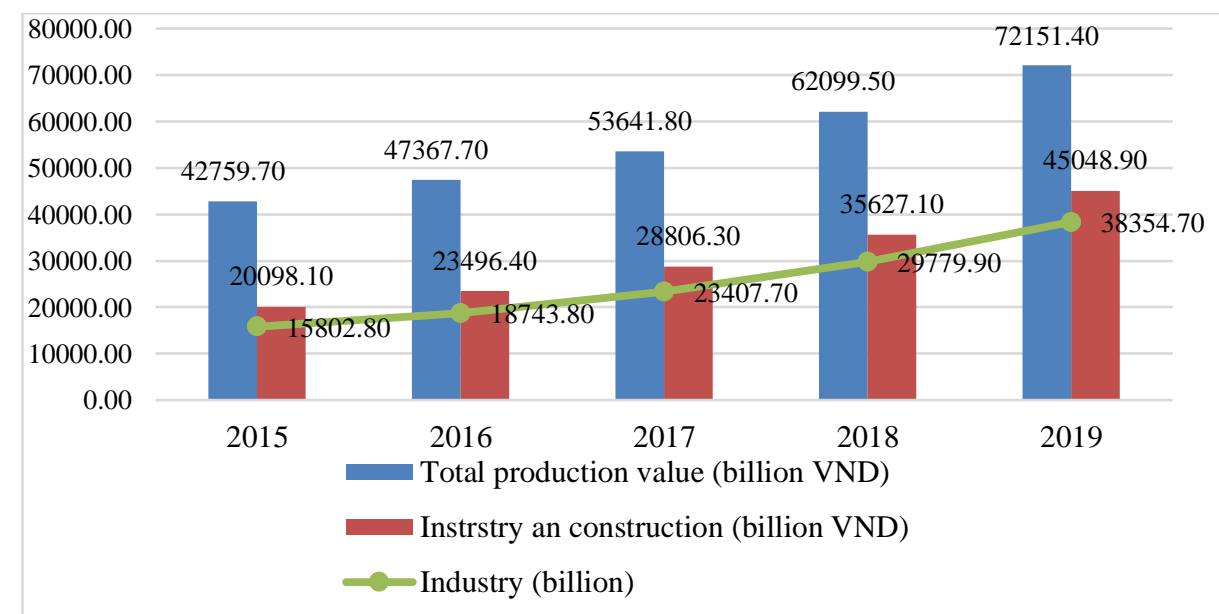

Fig. 1. Total value of industrial and construction production in Bac Giang province at constant prices 2010 (Bac Giang Statistical Office, 2020).

In general, the structure of industry - construction in the province tends to shift to increase the proportion of industry, and gradually decrease the proportion of construction. In terms of structural transformation, this trend is completely consistent with the increase in the value of the industry. The growth rate of production value of industry - construction of the district is higher than the average of the whole province. This shows that this is a premise in the process of attracting domestic and foreign investment capital into industrial zones in the district. 


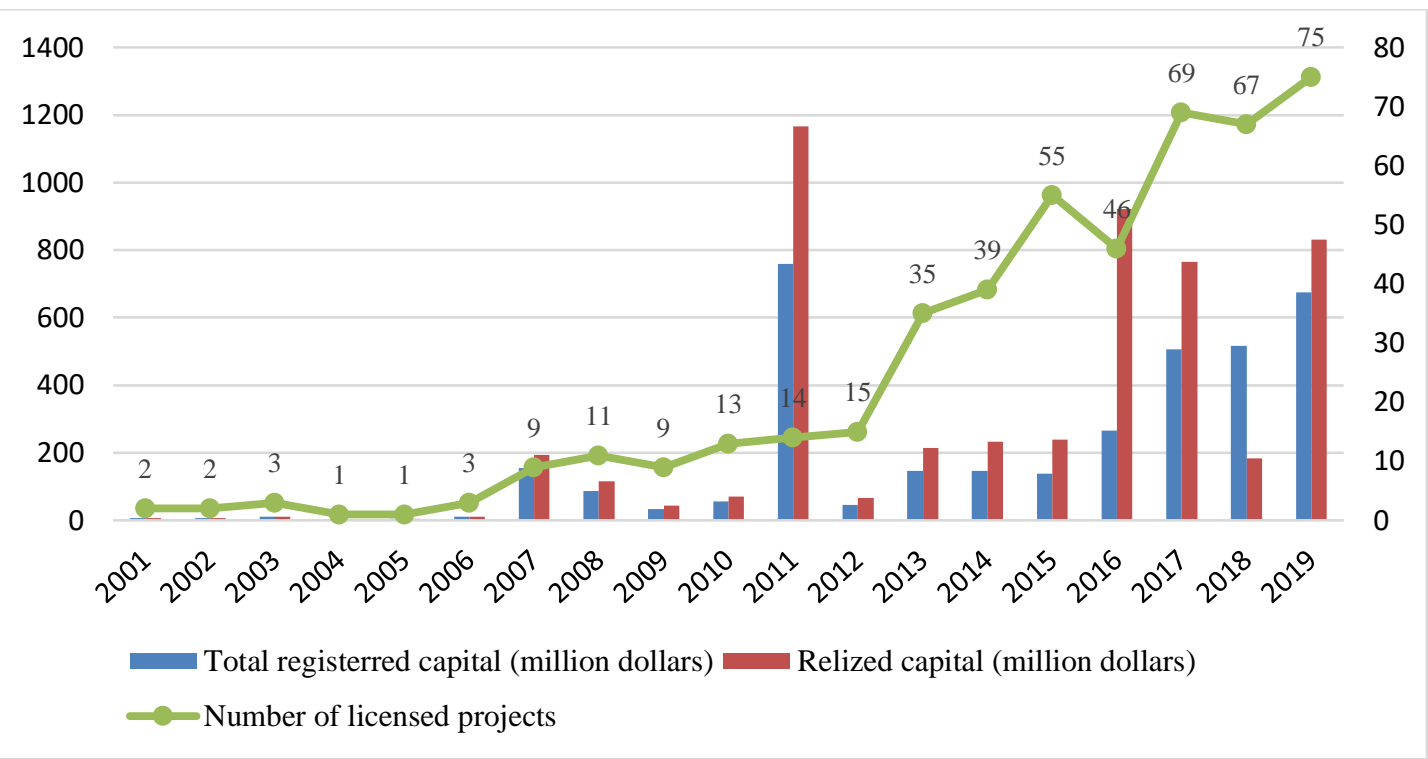

Fig.2. Foreign direct investment in Bac Giang province in the period 2001-2019 (Bac Giang Statistical Office, 2020).

The attraction of foreign investment capital to develop industrial zones is an important issue in national or local socio-economic development. Thanks to the appropriate policy, the number of investment projects within 20 tended to increase rapidly from 2 projects to 75 projects, in parallel with the increase in projects, the total registered capital and implemented capital also increased. Significant increasing trend in the period 2001-2019 (Fig. 2). Foreign direct investment capital is mainly concentrated in industrial zones. This shows a favorable direction in industrial park development. However, in the past, registered capital and charter capital were equivalent, but in recent years there is a significant difference in this amount.

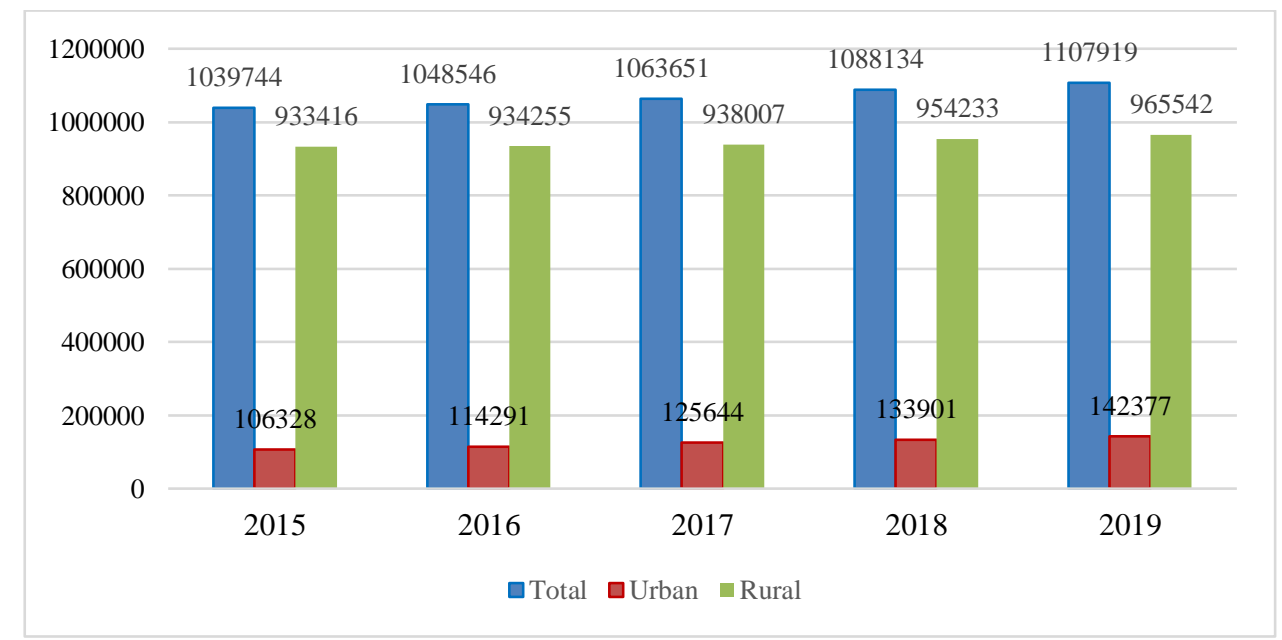

Fig. 3. Laborers from 15 years old are working by urban and rural areas (Bac Giang Statistical Office, 2020).

Besides, industrial park development attracts foreign investment, the province's abundant labor force also creates jobs for laborers. Industrial parks employ 164,000 workers in 2019 and this workforce is increasing (Pham Cong, 2021). Fig. 3 shows that although the labor force is abundant, the quality of labor is still not high. Because these workers mainly come from rural areas, with the traditional ideology of network production in the direction of "hereditary", the application of scientific advances in production is still limited.

\section{CONCLUSIONS AND RECOMMENDATION}

Bac Giang's industrial zones are in a period of rapid development, along with the appearance of industrial zones, the proportion of industry and foreign direct investment in the province increases and solves a large number of labors for the province and regions. close proximity. However, the increase is still limited. Besides, the labor force of the province comes mainly from the countryside, so the quality of labor is still not high, the ability to apply scientific advances to production is still limited. This makes it difficult to develop industrial zones in the province. In addition, the procedures to attract foreign 
investment capital are still difficult for investors. Therefore, the Government needs to create favorable legal corridors to attract foreign direct investment into industrial zones and encourage the formation of a training program for rural workers in industrial zone development. The province needs to take advantage of the Government's guidelines and policies in the development of industrial zones, coordinate with universities and colleges in the province to train human resources to serve industrial zones, businesses in industrial zones need to take advantage of this using government and local policies, as well as abundant labor resources to develop businesses.

\section{REFERENCES}

Anh, V.T.K. (2018). Sustainable Development of Vietnamese Industrial Zones: Case Study in Thai Binh Province. Journal of Trade Science6:4 (2018) $45-61$.

Bac Giang Statistical Office (2020). Bac Giang Statistical Yearbook 2020. Bac Giang Publishing house. Vietnam.

Central Executive Committee (2018). Resolution No. 23-NQ/TW dated March 22, 2018 of the Politburo on orientations for building national industrial development policies to 2030, with a vision to 2045. Ha Noi, Vietnam.

Sofer, M., Schnell, I., andDrori, I. (1996).Industrial Zones and Arab Industrialization in Israel.Human Organization,55(4), $465-474$.

Cong, P. (2021). Nearly 164,000 workers are working in industrial zones in Bac Giangprovince.https://dantri.com.vn/lao-dongviec-lam/gan-164000-lao-dong-dang-lam-viec-tai-cac-kcn-tinh-bac-giang-20210119132830534.htm.

Tien, P. N. (2006). The role of industrial parks and export processing zones in Vietnam's economic development. Journal of Economic Research,341.

Bakhtiyorovich, S. B., et al. (2020).Small industrial zones: a new approach to investment development in the Republic of Uzbekistan. PJAEE, 17(6).

Sosnovskikh,S. (2017). Industrial clusters in Russia: The development of special economic zones and industrial parks.Russian Journal of Economics 3, 174-199.

Cuc, T. T. \& Nguyen, T. A. (2021). Development of industrial parks and a new livelihood strategy for the people in Vietnam. Business perspective, 19(1), 221-230.

Hung, V. (2019). Bac Giang restricts investment projects outside industrial zones. https://bnews.vn/bac-giang-han-che-du-an-duocdau-tu-ngoai-khu-cong-nghiep/120720.html. 